\title{
Effect of Weight-bearing Pattern and Calcaneal Taping on Heel Width and Plantar Pressure in Standing
}

\author{
DoYoung Jung \\ Department of Physical Therapy, College of Health \& Welfare, Joongbu University, Geumsan, Korea
}

Purpose: This study examined the effects of the weight-bearing pattern and calcaneal taping on the heel width and plantar pressure in standing.

Methods: Fifteen healthy subjects with normal feet participated in this study. The heel width was measured using a digital caliper, and a pedoscan was used to measure the plantar pressure of the rear foot while standing. The participants were instructed to stand in three weight-bearing patterns (anterior, middle, and posterior weight bearing) before and after calcaneal taping. The heel width and plantar pressure were measured three times before and three times after calcaneal taping, with the three weight-bearing patterns applied in random order. A 2 (non-taping vs. taping) $\times 3$ (anterior, middle, posterior weight bearing) two-way repeated ANOVA with a Bonferroni post hoc correction was used to assess the differences in heel width and plantar pressure.

Results: The results revealed a significant main effect of the weight-bearing pattern $(p<.01)$, but not of calcaneal taping ( $p>.05)$. Greater weight bearing applied to the heel resulted in a significantly increased heel width and planter pressure of the rear foot $(p<.01)$.

Conclusion: In standing, a posterior weight-bearing pattern increases the heel width due to side-to-side shifting of the plantar heel pad, which increases the heel plantar pressure. Therefore, to prevent high stress on the heel pad and plantar heel pain, it is important to refrain from posterior weight bearing while standing during the activities of daily living.

Keywords: Calcaneal taping, Heel pad, Plantar heel pain

\section{서 론}

발바닥 뒤꿈치 통증(plantar heel pain)은 평생 동안 일반인들이 약 $10 \%$ 정도 경험하며, 운동 선수의 경우 발 질환의 $15 \%$ 를 차지하는 흔 한 증상이다.1,2 발바닥 뒤꿈치 통증은 발바닥 근막염(plantar fasciitis), 발꿈치벼 돌기(calcaneal spur), 발꿈치뼈 골절(calcaneal fracture), 발바 닥 근막 파열(rupture of plantar fascia), 발바닥 신경 포획(plantar nerve entrapment), 뒤꿈치 지방 패드의 위축과 탄성력 변화가 특징인 발뒤 꿈치 패드 증후군(heel pad syndrome)을 포함한 다양한 발 질환으로 인해 발생한다. 그 중 발바닥 근막염은 발바닥 뒤꿈치 통증이 특징 인 가장 흔한 발 질환의 원인이다. 40-60대 연령 그룹에서 가장 흔하 게 발생되며 서기와 보행과 같은 지속적인 체중지지활동, 제한된 발 목 관절의 발등굽힘, 그리고 과도한 엎침(pronation)과 뒤침(supination)을 포함하여 다양한 요인과 관련이 있다. ${ }^{45}$ 발바닥 근막염의 병 리학적 기전은 명확하게 알려지지 않았지만, 생검 연구 결과에 따르

Received Dec 31, 2019 Revised Feb 10, 2020

Accepted Feb 20, 2020

Corresponding author DoYoung Jung

E-mail ptsports@joongbu.ac.kr
면 발바닥 근막의 과도한 긴장과 또는 미세손상을 입은 환자에서 급 성 염증없이 2차성 퇴행성 변화로 일어난다고 보고하였다. ${ }^{6}$ 발뒤꿈치 패드 증후군은 종종 발바닥 근막염으로 잘못 진단된다.

뒤꿈치 패드 증후군은 맨발로 또는 단단한 지면에서 보행 시 발바닥 뒤꿈치에 심한 통증을 동반하며 발 뒤꿈치 패드의 염증 및 손상 뿐만 아니라 뒤꿈치 지방 패드의 위축(atrophy of heel fat pad)으로 인해 발생 된다. ${ }^{8}$ 뒤꿈치 지방 패드는 체중지지 활동 동안 충격을 흡수하고 진동 을 완화시킨다. ${ }^{9}$ 보행 중 뒤꿈치 패드의 변형으로 인해 발생하는 충격 에너지의 일부는 열로 소실되고 나머지는 탄성 에너지로 회복된다. 발 뒤꿈치 패드는 섬유질 격막(fibrous septa)과 밀집된 농축 지방 세포들 (packed fat cells)로 구성되어 발에 가해지는 스트레스에 견딜 수 있는 독 특한 해부학적 특징을 지닌다. 풍부한 콜라겐과 탄성 섬유(elastic fiber) 로 구성된 섬유질 격막은 밀집하게 농축된 구획에서 지방 폐쇄 공간 (adipose chamber)의 변형 또는 누출을 방지한다. 하지만 노화 된 발 뒤 꿈치 패드에는 지방 패드의 위축 혹은 섬유질 격막의 파열을 보인다.10
Copylight (C)2020 The Korean Society of Physical Therapy

This is an Open Access article distribute under the terms of the Creative Commons Attribution Non-commercial License (https:// creativecommons.org/license/by-nc/4.o.) which permits unrestricted non-commercial use, distribution, and reproduction in any medium, provided the original work is properly cited. 
뒤꿈치 지방 패드 위축은 40 세 이후에 물, 아교질(collagen) 및 탄성 조직(elastic fiber)의 손실을 동반된다. ${ }^{5}$ 이러한 조건 하에서, 체중지지 가 지속되는 동안 발꿈치뼈 주위 연부조직의 과부하로 인해 발바닥 뒤꿈치 통증과 부종이 동반되는 염증이 발생된다. 따라서 발 뒤꿈치 지방 패드로 인해 뒤꿈치 닿기(heel strike) 시 총 접촉 힘(total contact force)의 20-25\% 감소가 일어나기 때문에 발 뒤꿈치 지방 패드의 뺏뺏 함(stiffness)과 탄성(elasticity)이 충격 흡수 역할에 중요한 요인이다. 이 전 연구에 따르면 발 뒤꿈치 패드 증후군이 있는 발은 대조군 발보다 뻣뻣한 것으로 보고되었다.1112 또한 이전 연구들에서 발바닥 뒤꿈치 통증을 지닌 노인 환자의 발 뒤꿈치 패드의 탄력성을 알아보았 다.,13,14 Ozdemir 등 3 은 뒤꿈치 발바닥 통증이 있는 50 명의 대상자에 서 나이와 체중이 증가함에 따라 발 뒤꿈치 패드의 탄성이 감소한다 고 보고하였다. $\mathrm{Hsu}$ 등 ${ }^{13}$ 은 압축률 지수 (compressibility index: 하중을 가한 뒤꿈치 패드 두께에 대한 비 하중의 두께 비) 및 에너지 분산 비 (energy dispersion ratio)가 젊은 대상에 비해 노인 대상에서 더 크다는 것을 발견하였다. 정적인 선 자세에서 체중의 약 $60 \%$ 가 뒷발에 지지 되므로 뒤꿈치뼈 아래의 지방 패드의 질과 두께가 뒤꿈치 아래의 압 력에 영향을 주는 요인으로 작용한다.3.15,16

임상과 스포츠 분야에서 발바닥 뒤꿈치 통증 관리를 위해 휴식, 냉 요법, 항 염증제, 진통제, 종아리 근육 스트레칭, 힐컵(heel cup), 테이핑, 교정 신발 및 발 보조기 등의 다양한 방법이 사용되고 있다. 그중 발 보조기는 발바닥 근막염의 가장 흔한 증상인 발바닥 뒤꿈치 통증에 적용된다. ${ }^{17}$ 발 보조기의 힐컵의 기능은 뒤꿈치 패드에 더 많은 쿠션을 제공하여 뒤꿈치 닿기 시 뿐만 아니라 심지어 정적인 선 자세에서도 최대 힘을 줄인다. ${ }^{16}$ 또한 발꿈치 테이핑(calacaneal taping)은 지방 패드 위축 또는 탄력성 상실로 인한 발바닥 뒤꿈치 통증 환자에게 유용한 테이핑 방법이다. ${ }^{18}$ 하지만 아직까지 뒤꿈치 테이핑이 정적인 상태에서 의 뒤꿈치의 너비와 뒷발의 발바닥 압력에 미치는 영향을 알아본 연 구는 없는 실정이다. 정적으로 선 자세는 신발에 의해 발을 보호받지 못하는 실내에서 일하는 종사자들에게는 매우 중요하다. Page등 19 은 평상 시 정적인 선 자세에서의 체중지지 패턴이 뒤꿈치의 모양에 영향 을 미친다고 언급하였다. 뒤에서 뒤꿈치를 관찰했을 때 사각형 모양은 무게 중심이 발 뒤쪽으로 이동되어 있고 보행 중에 발 뒤꿈치에 과도 한 힘을 가할 수 있는 반면에 뾰족한 형태의 뒤꿈치는 무게중심이 발 앞쪽으로 위치해 있고 보행 시 앞발에 과도한 스트레스를 줄 수 있다 고 언급하였다. 하지만 아직까지 체중지지 패턴이 뒤꿈치 모양에 미치 는 영향을 알아본 연구는 없는 실정이다. 따라서 본 연구에서는 뒤꿈 치 테이핑 전후 정적인 선 자세에서의 체중지지 패턴이 뒤꿈치의 너비 와 뒷발의 발바닥 압력에 미치는 영향을 알아보고자 하였다. 본 연구 에서는 뒷발로 체중이 가해 질수록 뒤꿈치의 너비가 증가되고 뒷발의 발바닥 압력이 증가할 것이며, 뒤꿈치 테이핑이 뒤꿈치의 너비와 뒷발
의 발바닥압력을 감소시킬 것이다고 가설을 세웠다.

\section{연구 방법}

\section{1. 연구대상}

본 연구에서는 정적인 선 자세에서 발목관절 및 발바닥에 통증이 없 는 성인 15명(남성: 6명, 여성: 9명)을 대상으로 실험하였다. 실험 대상 자들의 평균 나이 $22.2 \pm 71.6$ 세, 평균 체중 $57.1 .4 \pm 11.2 \mathrm{~kg}$, 그리고 평균 신장은 $166.2 \pm 48.1$ 이었다. 참가자 중 발목 관절의 수술 경험, 골절 또는 신경학적 문제가 있는 경우 그리고 테이핑 적용 시 알러지 반응 경험 이 있는 대상자들은 제외시켰다. 대학 내 게시판과 구두설명을 통해 대상자들을 모집하였고 실험에 시작하기에 앞서 모든 과정을 대상자 에게 설명하였으며 실험 참여에 동의한 대상자들로만 실험하였다.

\section{2. 실험방법}

\section{1) 측정도구}

체중지지 패턴(앞쪽, 중간, 뒤쪽)에 따른 뒷발의 최대 발바닥 압력을 측정하기 위해 매트 타입의 압력센서가 있는 발바닥 압력 측정기(Pedoscan, DIERS Inc., Germany)를 사용하였다. 뒷발의 최대 발바닥 압 력은 Pedoscan의 DICAM 프로그램 이용하여 자료를 수집하였다. 매 트는 4,096 압력 센서로 구성되었으며, 너비와 길이는 각각 $50 \mathrm{~cm}$ 이다. 표본 추출률은 $300 \mathrm{~Hz}$ 이다.20,21 뒤꿈치 테이핑은 폭이 $4 \mathrm{~cm}$ 인 비탄 력 백색 테이프 (PerformPlus, Muller Sports Medicine Inc., Wisconsin, USA)를 사용하였다. 뒤꿈지 테이핑 전후의 뒤꿈치 너비를 측정하기 위해 디지털 캘리퍼(Digimaic Caliper, CD-20APX, Mitutoyo Corporation, Japan)가 사용되었다.

\section{3. 실험 과정}

각각의 참가자들은 뒤꿈치 테이핑 전후의 3 가지 체중지지 패턴(앞쪽, 중간, 뒤쪽)으로 발바닥 압력 측정기 위에 정적으로 선 자세를 유지 하도록 하였다. 정적인 선 자세 동안 각 조건에서 뒷발의 발바닥 압력 을 5 초 동안 수집하였고 안쪽과 바깥쪽 복숭아 뼈 뒤쪽 모서리에서

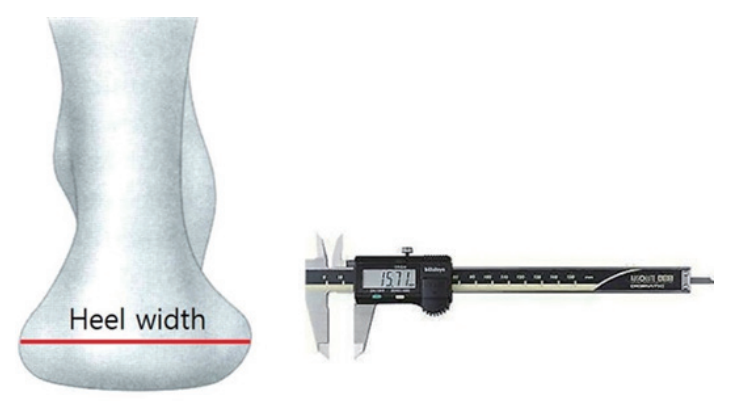

Figure 1. Measurement of heel width 

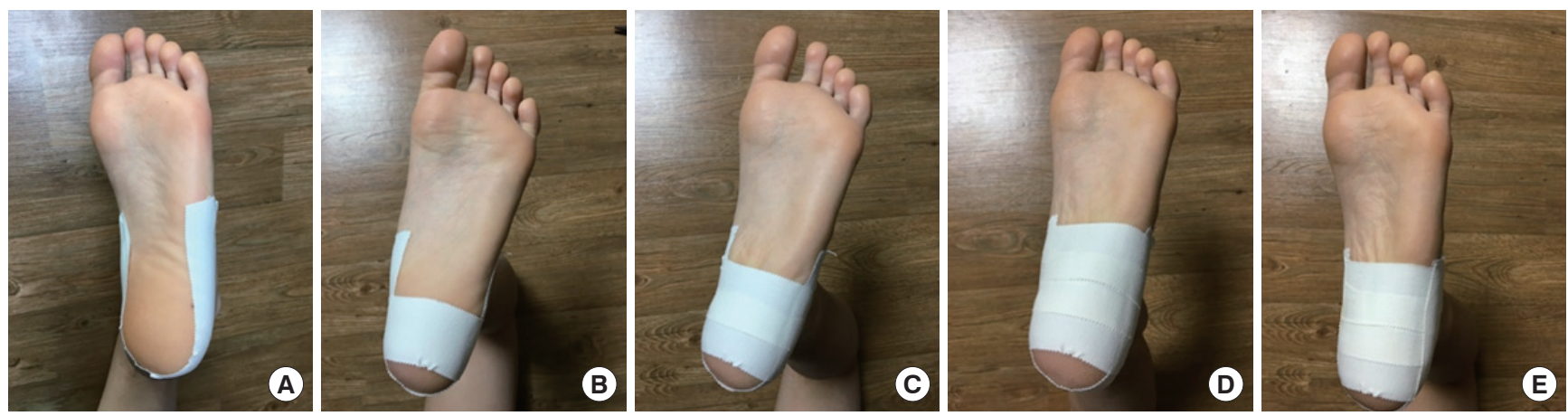

Figure 2. Procedure of calcaneal taping

아래로 내려와 가장 많이 돌출된 뒤꿈치 너비를 디지털 캘리퍼를 이 용하여 측정하였다(Figure 1). 뒤꿈치 너비와 뒷발의 발바닥 압력은 뒤꿈치 테이핑 전과 후에 3 가지 체중 지지 패턴 조건 들을 무작위로 적용하여 측정하였다. 선 자세에서 앞쪽 혹은 뒤쪽 체중 지지 패턴은 대상자가 팔짱을 낀 상태에서 각각 뒤꿈치가 들리지 않거나 앞발이 들리지 않는 범위에서 최대한 체간을 앞쪽 혹은 뒤쪽으로 기울렸으 며 중간 체중 지지 패턴은 평상 시 편안한 자세로 서게 하였다.

발꿈치 테이핑 적용을 위해, 바로 누운 자세에서 검사 발을 침대 끝 가장자리로부터 $10 \mathrm{~cm}$ 정도 나오게 하였다. 고정 테이프(anchor taping)를 발꿈치입방관절(calcaenocuboid joint)에서 목말발배관절(talonavicular joint)까지 가쪽에서 안쪽으로 적용하였다(Figure 2A). 한 손 으로 엄지와 검지를 활용하여 뒤꿈치의 안쪽과 가쪽 테두리에 있는 지방 패드를 눌러 뒤꿈치 발바닥으로 최대한 모으게 하고 테이프를 뒤꿈치 주변의 가쪽에서 안쪽 방향으로 적용하였다(Figure 2B). 두 번 째 테이프를 전 테이프의 절반을 겹치게 하여 적용하였다(Figure 2C). 대상자의 발 크기에 따라 세 번째 또는 네 번째 테이프를 몸쪽으로 전에 적용했던 테이프의 절반을 겹치게 하면서 반복하여 적용하였 다(Figure 2D). 두 번째 고정 테이프를 첫 번째 고정 테이프와 동일하 게 테이프가 떨어지지 않도록 적용한다. 마지막으로 테이프가 견고하 게 부착이 되었는지 확인하였다.

\section{4. 자료 처리 및 통계방법}

모든 데이터는 통계 프로그램 SPSS version 17.0 (SPSS Inc., Chicago, IL, USA)을 통해 분석하였다. 일표본 Kolmogorov-Smirnov 검정을 통해 측정 데이터의 정규 분포를 확인하였다. 3 회 반복 측정된 뒤꿈치 너비 와 뒷발의 발바닥 압력을 평균값으로 계산하였다. 반복측정 된 뒤꿈 치 너비와 뒤꿈치 발바닥 압력의 검사-재검사 신뢰도를 알아보기 위 해 급간내 상관관계 계수(intraclass correlation coefficient; $\operatorname{ICC}(3,1)$ )를 계산하였다. 테이핑 전 후 체중지지 패턴이 뒤꿈치 너비와 뒷발의 발 바닥 압력의 차이를 알아보기 위해 2 (비 테이핑 X 테이핑) $\times 3$ (전방 X 중간 $\mathrm{X}$ 후방 체중 지지 자세) 반복측정된 이요인 분산분석 방법(two- way repeated ANOVA)을 사용하였다. 통계학적 유의성 검증을 위한 유의수준은 $\alpha=0.05$ 로 하였다. 사후 검정으로 체중 지지 패턴에 따른 뒤꿈치 너비와 뒤꿈치 발바닥 압력의 차이를 알아보기 위해 본페르 니 교정 t-검정 (paired-sample t test with Bonferroni correction) 분석을 실시였으며 이때 유의수준은 $0.016(0.05 / 3)$ 로 하였다.

\section{결 과}

반복측정 된 뒤꿈치 너비와 뒷발의 발바닥 압력의 검사-재검사 신뢰 도는 모두 높았다 (뒤꿈치너비: ICC $3,1=0.99$, 뒤꿈치 발바닥 압력: ICC $3,1=0.86$ ). 테이핑 유무와 체중지지 패턴에 따른 뒤꿈치 너비와 뒷 발의 발바닥 압력은 Tables 1, 2에 제시하였다. 테이핑 유무와 체중지 지 패턴이 뒤꿈치 너비와 뒷발의 발바닥 압력 차이를 알아보기 위한 반복측정 이요인 분산분석 결과, 뒤꿈치 너비에 대한 체중지지 패턴 의 주 효과에서는 유의한 차이가 있었지만(F1,14=55.2, $\mathrm{p}=0.01)$, 테이 핑 유무에 따른 주 효과에서는 유의한 차이가 없었다 $(\mathrm{F} 1,14=4.3$, $\mathrm{p}=0.06$ ). 또한 뒤꿈치 발바닥 압력 대한 체중지지 패턴의 주 효과에 서는 유의한 차이가 있었지만(F1,14=13.5, $\mathrm{p}=0.01$ ), 테이핑 유무에 따 른주 효과에서는 유의한 차이가 없었다( $\mathrm{Fl}, 14=1.9, \mathrm{p}=0.19)$.

사후분석 결과, 뒤꿈치 너비는 테이핑 유무에 상관없이 체중지지 패턴 모든 조건 사이에 유의한 차이를 보였으며( $\mathrm{p}<0.016$ )(Figure 3A), 테이핑 없는 조건에서 뒷발의 발바닥 압력은 뒤쪽 체중지지 조건이 중간 체중지지 조건보다 유의하게 높았으며, 테이핑 적용 조건에서는 뒷발의 발바닥 압력은 뒤쪽 체중지지 조건이 앞쪽 체중지지 조건보 다 유의하게 높았다 $(\mathrm{p}<0.016)$ (Figure 3B).

\section{고 찰}

본 연구에서는 뒤꿈치 테이핑이 뒤꿈치 주변의 안쪽과 바깥쪽에 있 는 지방 패드를 뒷발의 발바닥 중앙으로 모아 적용하였기 때문에 정 적인 선 자세에서 뒷발의 최대 발바닥 압력이 감소될 수 있을 것이다 
Table 1. Descriptive statistics for heel width according to weight-bearing pattern and taping

(unit: $\mathrm{mm}$ )

\begin{tabular}{lccc}
\hline \multirow{2}{*}{ Conditions } & \multicolumn{3}{c}{ Weight-bearing pattern } \\
\cline { 2 - 4 } & Anterior & Middle & Posterior \\
\hline Non-taping & $56.98 \pm 5.85$ & $58.71 \pm 5.70$ & $59.17 \pm 5.84$ \\
Taping & $56.05 \pm 5.27$ & $57.84 \pm 5.02$ & $58.07 \pm 4.93$ \\
\hline
\end{tabular}

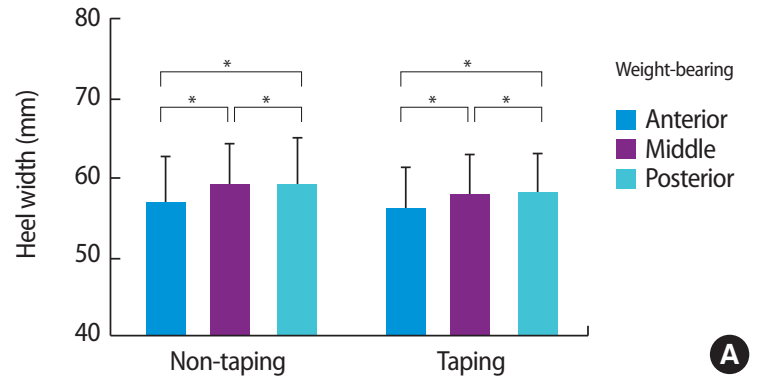

Table 2. Descriptive statistics for planter pressure of rearfoot according to weight-bearing pattern and taping

(unit: $\mathrm{N} / \mathrm{cm}^{2}$ )

\begin{tabular}{lrcc}
\hline \multirow{2}{*}{ Conditions } & \multicolumn{3}{c}{ Weight-bearing pattern } \\
\cline { 2 - 4 } & Anterior & Middle & Posterior \\
\hline Non-taping & $10.90 \pm 1.83$ & $10.82 \pm 2.55$ & $13.09 \pm 2.48$ \\
Taping & $9.93 \pm 1.83$ & $10.68 \pm 1.89$ & $12.55 \pm 2.39$ \\
\hline
\end{tabular}

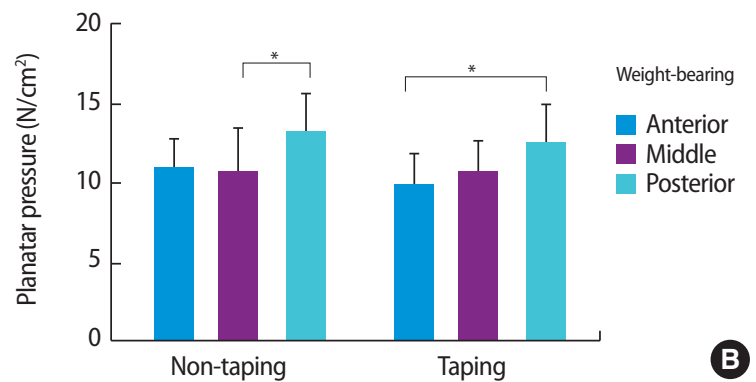

Figure 3. Result of post hoc in heel width $(A)$ and plantar pressure of rearfoot $(B)$ according to weight-bearing pattern and taping $(* \mathrm{p}<0.016)$

라고 가설을 세웠다. 하지만 본 연구 결과, 정적인 선 자세에서 세 가 지 체중지지 패턴 간에 뒷발의 발바닥 압력에는 유의한 차이를 보였 으나, 발꿈치 테이핑 유무에 따른 뒷발의 최대 발바닥 압력에는 유의 한 차이가 없었다. 이전 연구들에서 선 자세 혹은 보행 시 뒤꿈치 지 방패드의 두께를 유지하기 위한 힐컵, 힐인서트 그리고 힐카운터와 같은 다양한 방법들을 언급하였다. ${ }^{16,18,22,23}$ Perhamre 등 ${ }^{16}$ 은 Sever's 손 상이 있는 아동을 대상으로 발 뒤꿈치 부위의 연부조직들의 변위를 제한하는 힐컵이 맨발 보다 발바닥 뒤꿈치 지방 패드의 두께를 3.57 $\mathrm{mm}$ 증가시켰고 뒷발의 압력은 $25 \%$ 감소했다고 보고하였다. 또한 Ohuchi 등 22 은 힐컵 보조기가 선 자세에서 $1.25 \mathrm{~mm}$ 증가시켰고 아치 의 높이를 증가시켰다고 보고하였다. 비록 본 연구에서는 뒤꿈치 테 이핑 적용 전후에 뒤꿈치 아래의 지방 패드 두께를 측정하지 못하였 지만, 뒤꿈치 너비를 약 $1 \mathrm{~mm}$ 감소시켰으나 뒷발의 발바닥 압력에서 는 유의한차이가 없었다. Weon 등 18 은 발꿈치 테이핑이 보행 시 뒷발 의 안쪽과 바깥쪽 부위 발바닥 압력을 감소 시켰다고 보고하였다(안 쪽 부위: 평균 차이 $=1.3 \mathrm{~N} / \mathrm{cm}^{2}$; 바깥쪽 부위: 평균 차이 $=0.8 \mathrm{~N} / \mathrm{cm}^{2}$ ). 이전 연구와 본 연구의 결과가 다른 이유는 발꿈치 테이핑에 의한 뒷 발 발바닥에 모아둔 뒤꿈치 지방 패드가 정적인 선 자세보다 보행 시 발바닥압력에 더 큰 영향을 미쳤을 것으로 예상된다.

본 연구결과, 정적인 선 자세에서 앞발에서 뒷발로 체중을 지지 할 수록 뒷발의 최대 발바닥 압력과 뒤꿈치 너비가 유의하게 증가하였 다. Page 등 ${ }^{20}$ 은 정적인 선 자세에서의 뒤꿈치가 사각형 모양일 경우 무게 중심이 발 뒤쪽으로 이동되어 있고 보행 중에 발 뒤꿈치에 과도 한 힘을 가할 수 있는 반면에 반면, 뾰족한 모양의 뒤꿈치는 무게중심 이 발 앞쪽으로 위치해 있고 보행 시 앞발에 과도한 스트레스를 줄수 있다고 언급하였다. 본 연구에서는 위 관련 문헌에서 언급한 내용을
실험을 통해 증명하였다. 비록 본 연구에서 뒤꿈치 아래 지방패드의 두께를 측정하지 못했지만, 이러한 결과는 뒷발로 체중이 이동할 수 록 뒤꿈치 아래 지방패드가 뒤꿈치 안쪽과 가쪽으로 이동되어 뒤꿈 치의 너비가 증가되고 발바닥 압력이 증가했을 것으로 사료된다. 따 라서 정적인 선 자세에서 발 뒤꿈치 모양에 따라 앞발과 뒷발의 체중 분포도 비를 알아볼 수 있을 것으로 기대된다. 향후 연구에서는 뒤꿈 치 패드 증후군 유무에 따른 뒤꿈치 모양을 알아보고, 뒤꿈치 모양에 따른 앞발과 뒷발의 체중분포도 비를 알아볼 필요가 있다. 몇몇 연구 들에서 지방 패드의 두께와 발바닥 통증의 역학적 특성간의 관계를 분석했었다. ${ }^{3,24} \mathrm{Ozdmir}$ 등 ${ }^{3}$ 은 지방 패드의 두께 변화에 따른 탄성의 감소는 발바닥 통증에 기여한다고 보고하였다. 이러한 발바닥의 형 태학적인 변화는 나이와 몸무게의 증가와 관련이 있다. Lopez-Lopez 등 24 은 뒤꿈치 발바닥 통증 그룹이 대조군에 비해 뒤꿈치 발바닥 지 방패드의 두께가 더 작다고 보고하였다. 비록 본 연구에서는 평상 시 정적인 선 자세에서의 체중지지 패턴과 통증과의 관련성을 알아보지 못했지만, 정적인 선 자세에서 뒷발로 체중지지 패턴이 뒤꿈치 압력 과 너비를 증가시키는 결과로 미루어 볼 때, 향후 연구에서 앞발과 뒷 발 간 체중지지 패턴과 뒤꿈치 발바닥 통증과의 관련성을 알아봄으 로써 뒤꿈치 발바닥 통증을 예방하거나 관리하기 위한 기초자료로 활용될 수 있을 것으로 기대된다.

몇몇 이전 연구에서 뒤꿈치에 가해지는 하중 정도에 따른 초음파 와 방사선 장비를 활용하여 뒤꿈치 발바닥 지방패드의 두께를 알아 보았다. ${ }^{12,25}$ 그 중 Uzel 등 ${ }^{25}$ 은 누운자세에서의 비하중과 선 자세에서 의 하중 시 지방패드의 두께가 각각 $19.8 \mathrm{~mm}$ 와 $12.3 \mathrm{~mm}$ 로 $7.5 \mathrm{~mm}$ 의 차이를 보였다. 본 연구에서는 앞발과 뒤발 체중지지 패턴간의 뒤꿈 치 너비의 차이가 $2.2 \mathrm{~mm}$ 였다. 비록 본 연구에서는 지방패드의 두께 
를 측정하지 못했지만 뒷발로 체중지지가 가해질수록 지방 두께 손 실이 증가됨에 따라 뒤꿈치 너비가 증가했을 것으로 추측된다. 또한 반복측정된 뒤꿈치 너비의 검사-재검사 신뢰도가 0.99 로 매우 높았 으므로 향후 연구에서 뒤꿈치 너비가 지방패드의 두께를 간접적으 로 알아볼 수 있는 변수로서 활용할 수 있는 지 알아보기 위해 앞발 과 뒤발 간의 체중지지 패턴에 따른 지방패드의 두께와 뒤꿈치 너비 와상관관계를 알아볼 필요가 있을 것이다.

본 연구에는 몇 가지 제한점이 있다. 첫째, 테이핑 적용 시 뒤꿈치 너비 측정 값에서 테이핑의 두께를 빼지 않았다. 실질적인 뒤꿈지의 너비는 테이핑 적용 전후 더 많은 차이를 보였을 것으로 사료된다. 둘 째, 본 연구의 결과는 모든 성인에게 일반화하기 어렵다. 지방 패드의 위축은 주로 40 세 이상의 성인에서 발생하지만 본 연구에서의 대상 자 평균 연령은 22 세이므로 모든 성인을 대표 할 수는 없다. 셋째, 발 바닥 뒤꿈치 통증이 있는 환자의 뒤꿈치 너비 변화 결과가 정상 발의 결과와 동일한 지 여부는 알 수 없다. 마지막으로, 본 연구에서 테이핑 은 정상 대상자에게 적용하였으므로 발바닥 뒤꿈치 통증이 있는 환 자의 발바닥 압력에 차이를 보이는지 여부를 알 수 없었다. 따라서 발 바닥 뒤꿈치 통증이 있는 환자와 정상인과의 체중지지 패턴, 뒤꿈치 너비와 뒤꿈치 지방 패드 높이를 비교하고, 발꿈치 테이핑이 이러한 변수와 통증에 미치는 영향을 알아볼 필요가 있다.

\section{ACKNOWLEDGMENTS}

This paper was supported by Joongbu University Research \& Development Fund, in 2019

\section{REFERENCES}

1. Riddle DL, Pulisic M, Pidcoe P, et al. Risk factors for Plantar fasciitis: a matched case-control study. J Bone Joint Surg Am. 2003;85(5):872-7.

2. Taunton JE, Ryan MB, Clement DB, et al. A retrospective case-control analysis of 2002 running injuries. Br J Sports Med. 2002;36(2):95-101.

3. Ozdemir H, Soyuncu Y, Ozgorgen M, et al. Effects of changes in heel fat pad thickness and elasticity on heel pain. J Am Podiatr Med Assoc. 2004;94(1):47-52.

4. Buchbinder R. Clinical practice. Plantar fasciitis. N Engl J Med. 2004; 350(21):2159-66.

5. Neufeld SK, Cerrato R. Plantar fasciitis: Evaluation and treatment. J Am Acad Orthop Surg. 2008;16(6):338-46.

6. Lemont H, Ammirati KM, Usen N. Plantar fasciitis: a degenerative process (fasciosis) without inflammation. J Am Podiatr Med Assoc. 2003; 93(3):234-7

7. Yi TI, Lee GE, Seo IS, et al. Clinical characteristics of the causes of plantar heel pain. Ann Rehabil Med. 2011;35(4):507-13
8. Tu P, Bytomski JR. Diagnosis of heel pain. Am Fam Physician. 2011; 84(8):909-16.

9. Prichasuk S. The heel pad in plantar heel pain. J Bone Joint Surg Br 1994; 76(1):140-2.

10. Bennett MB, Ker RF. The mechanical properties of the human subcalcaneal fat pad in compression. J Anat 1990;171:131-8.

11. Rome K, Webb P, Unsworth A, et al. Heel pad stiffness in runners with plantar heel pain. Clin Biomech (Bristol, Avon). 2001;16(10):901-5.

12. Tsai WC, Wang CL, Hsu TC, et al. The mechanical properties of the heel pad in unilateral plantar heel pain syndrome. Foot Ankle Int. 1999; 20(10):663-8.

13. Hsu TC, Wang CL, Tsai WC, et al. Comparison of the mechanical properties of the heel pad between young and elderly adults. Arch Phys Med Rehabil 1998;79(9):1101-4.

14. Wearing SC, Smeathers JE, Urry SR. The effect of plantar fasciitis on vertical foot-ground reaction force. Clin Orthop Relat Res. 2003; (409):17585.

15. Perhamre S, Lundin F, Klassbo M, et al. A heel cup improves the function of the heel pad in Sever's injury: effects on heel pad thickness, peak pressure and pain. Scand J Med Sci Sports. 2012; 22(4):516-22.

16. Sweeney D, Nester C, Preece S, et al. Effect of antipronation foot orthosis geometry on compression of heel and arch soft tissues. J Rehabil Res Dev. 2015;52(5):543-51

17. Rasenberg N, Riel H, Rathleff MS, et al. Efficacy of foot orthoses for the treatment of plantar heel pain: a systematic review and meta-analysis. Br J Sports Med. 2018;52(16):1040-6.

18. Weon JH, Kim GS, Jung DY. Effect of Calcaneal Taping on Peak Plantar Pressure of Forefoot and Rearfoot during Gait. J Korean Soc Phys Ther. 2015;27(6):434-8

19. Page P. Frank CC, Lardner R. Assessment and Treatment of Muscle Imbalance: The Janda Approach First Edition: Human Kinetics, Inc.; First edition. 2009

20. Choi HJ, Nam KW. The Effect of Horseback Riding Simulator on Static Balance of Cerebral Palsy. J Korean Soc Phys Ther. 2014;26(4):269-73.

21. Yang DJ, Park SK, Kang JI, et al. Effects of Changes in Postural Alignment on Foot Pressure and Balance of Patients with Stroke. J Korean Soc Phys Ther. 2014;26(4):226-33.

22. Ohuchi H, Chavez JS, Alvarez CAD. Changes in calcaneal pitch and heel fat pad thickness in static weight bearing radiographs while wearing shoes with arch support and heel cup orthotics. Asia Pac J Sports Med Arthrosc Rehabil Technol. 2019;17:21-4.

23. Spears IR, Miller-Young JE, Sharma J, et al. The potential influence of the heel counter on internal stress during static standing: a combined finite element and positional MRI investigation. J Biomech. 2007;40(12): 2774-80.

24. Lopez-Lopez D, Becerro-de-Bengoa-Vallejo R, Losa-Iglesias ME, et al. Relationship Between Decreased Subcalcaneal Fat Pad Thickness and Plantar Heel Pain. A Case Control Study. Pain Physician. 2019;22(1): 109-16.

25. Uzel M, Cetinus E, Bilgic E, et al. Comparison of ultrasonography and radiography in assessment of the heel pad compressibility index of patients with plantar heel pain syndrome. Measurement of the fat pad in plantar heel pain syndrome. Joint Bone Spine. 2006;73(2):196-9. 